\title{
EQUILIBRIUM
}

Quarterly Journal of Economics and Economic Policy

2015 VOLUME 10 ISSUE 2, June

p-ISSN 1689-765X, e-ISSN 2353-3293

www.economic-policy.pl

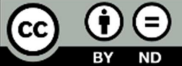

Mackiewicz-Łyziak, J. (2015). Fiscal Sustainability in CEE Countries - the Case of the Czech Republic, Hungary and Poland. Equilibrium. Quarterly Journal of Economics and Economic Policy, 10(2), pp. 53-71, DOI: http://dx.doi.org/10.12775/ EQUIL.2015.013

Joanna Mackiewicz-Łyziak*

Warsaw University, Poland

\section{Fiscal Sustainability in CEE Countries - the Case of the Czech Republic, Hungary and Poland**}

JEL Classification: E62; H62; H63

Keywords: fiscal sustainability; monetary and fiscal dominance; primary balance; debt; cointegration

\begin{abstract}
The aim of the study is to assess fiscal sustainability in the Czech Republic, Hungary and Poland, and to test for existence of fiscal dominance in these countries in the context of the fiscal theory of the price level. The empirical study is conducted using unit root tests and co-integration analysis with possible structural breaks. The approach is consistent with so called backward-looking approach for fiscal dominance testing proposed by Bohn (1998). The results suggest that in the Czech Republic and Poland fiscal dominance prevailed in the analyzed period, while in Hungary - monetary dominance. The result for Hungary may be caused, however, by a one-time reduction in debt resulting from changes in pension system.
\end{abstract}

(C) Copyright Institute of Economic Research \& Polish Economic Society Branch in Toruń Date of submission: December 28, 2014; date of acceptance: June 1, 2015

*Contact: e-mail: jmackiewicz@wne.uw.edu.pl, Faculty of Economic Sciences, Warsaw University, ul. Długa 44/50, 00-241 Warszawa, Poland

** The author gratefully acknowledges the support of the National Science Centre (decision no. DEC-2012/07/B/HS4/00318) 


\section{Introduction}

During and after the global financial crisis many countries saw a significant loosening of fiscal policy. Considering that in many European countries public debt levels were already high even before the outburst of the crisis, the worsening of the public finances raised questions about the sustainability of the fiscal policy. In this context, concerns have also arisen about the consequences of fiscal imbalances for the effectiveness of monetary policy. As the "unpleasant monetarist arithmetic" by Sargent and Wallace (1981) shows, price stability requires an appropriate fiscal policy. If the public debt is too high, the monetary authorities will finally lose control over inflation. This concept has been further developed by the fiscal theory of the price level (FTPL). FTPL claims that the intertemporal government budget constraint may be satisfied (which means that the fiscal solvency condition may be fulfilled) in two ways: through adjustment of the primary surplus - which is called the Ricardian or monetary dominant regime, or through the endogenous adjustment of the price level - which is called the nonRicardian or fiscal dominant regime. Therefore, the fiscal imbalances and the lack of adjustment of the fiscal policy may threaten the overall economic stability.

The aim of the paper is to test for fiscal sustainability and fiscal dominance in three CEE countries: the Czech Republic, Hungary and Poland over the period Q1:2000-Q3 2013. The test consists in analyzing the statistical properties of the fiscal variables time-series and the long-term relationship between primary surplus and public debt, as described below in detail. Although the fiscal situation varied across the countries, the public debt rose in all of them substantially over the analyzed period. Therefore, it seems important to test for the presence of fiscal dominance, for it may undermine the ability of the countries' central banks to achieve their inflation targets.

The paper is organized as follows. In the next section, we refer to the fiscal theory of the price level as the theoretical guidelines how to distinguish between monetary dominance and fiscal dominance. In the third section empirical methodology is described in detail. The fourth section presents the countries' recent fiscal policy developments and results of the empirical study of the long-term relationship between governments primary balance and debt. Finally, last section offers some concluding remarks. 


\section{Theoretical Background}

The fiscal theory of the price level states that, in general, a proper monetary policy is not sufficient to ensure the stability of the price level. The price stability also requires an appropriate fiscal policy. This possibility first formulated Sargent and Wallace (1981) in their "unpleasant monetarist arithmetic". They showed that if the government finances its debt from taxes and seignorage, too loose fiscal policy may force the central bank to increase seignorage, in order to guarantee the fulfillment of the government budget constraint. In consequence, this would lead to higher inflation. FTPL (Woodford, 1994, pp. 345-389; 1995, pp. 1-46; 1996; 1998; 2001, pp. 669-728; Sims, 1994, pp. 381-399; 1999; Leeper, 1991, pp. 129-147; Cochrane, 2000; 2001, pp. 69-116) develops this concept.

In order to obtain the fiscal solvency conditions, we can write the intertemporal (present-value) government budget constraint:

$$
b_{t}=\sum_{i=0}^{\infty}\left(\frac{1+y}{1+r}\right)^{i+1} E_{t} s_{t+i+1}+\lim _{i \rightarrow \infty}\left(\frac{1+y}{1+r}\right)^{i+1} E_{t} b_{t+i+1}
$$

where $b$ denotes public debt in relation to GDP, $s$ - primary surplus to GDP, $\mathrm{y}$ - growth rate of real GDP, $\mathrm{r}$ - real interest rate and $\mathrm{E}$ is a expectations operator. Both $y$ and $r$ are assumed to be constant.

Therefore, we can write the condition for fiscal solvency as:

$$
\lim _{i \rightarrow \infty}\left(\frac{1+y}{1+r}\right)^{i+1} E_{t} b_{t+i+1}=0
$$

which means that the present value of the public debt must approach zero in infinity for the fiscal policy sustainable, or:

$$
b_{t}=\sum_{i=0}^{\infty}\left(\frac{1+y}{1+r}\right)^{i+1} E_{t} s_{t+i+1}
$$

which means that the current debt must be equal to the sum of expected future primary surpluses expressed in present value term. The two conditions are, of course, equivalent (based on Bajo-Rubio et al., 2009, pp. 924937).

According to the FTPL, two regimes may be distinguished, depending on the way the fiscal solvency is guaranteed. In the Ricardian, or monetary dominance regime, fiscal policy adjusts in such a way that the intertemporal government budget constraint is satisfied, regardless of the price 
level. In contrast, in non-Ricardian, or fiscal dominance regime, fiscal policy is conducted in such a way that the intertemporal budget constraint would not be satisfied for all possible price levels (Christiano \& Fitzgerald, 2000). In this situation the price level is endogenous and adjusts to ensure fiscal solvency. We can rewrite equation [3] to illustrate this:

$$
\frac{B_{t}}{P_{t} Y_{t}}=\sum_{i=0}^{\infty}\left(\frac{1+y}{1+r}\right)^{i+1} E_{t} S_{t+i+1}
$$

where $\mathrm{B}$ denotes the public debt in nominal terms, $\mathrm{P}$ is the price level and $\mathrm{Y}$ is the real GDP.

If all other variables, in particular B, s and Y, are set, the only possibility for the government budget constraint to be satisfied is the adjustment of P. Therefore, according to FTPL, even delegating monetary policy to an independent central bank with strong mandate for price stability, like in inflation targeting countries, may be insufficient to ensure the price level to be really stable.

\section{Methodology}

The tests for the fiscal dominance conducted in the spirit of the fiscal theory of the price level may be divided into two approaches: the so called backward-looking approach, and the forward-looking approach. The backward-looking approach, formulated by Bohn (1998, pp. 949-963) and Bohn (2007, pp. 1837-1847), implies that in a monetary dominant (Ricardian) regime, an increase in the past levels of the public debt would lead to a present primary surplus, to ensure solvency. And vice versa - in the fiscal dominant (non-Ricardian) regime we would not expect to observe such a relationship. The other approach, namely forward-looking approach introduced by Canzoneri et al. (2001, pp. 1221-1238), postulates that in a Ricardian regime a larger primary surplus today would cause a reduction in the future levels of debt.

In this study, the first approach is followed to analyze the fiscal policy sustainability in the Czech Republic, Hungary and Poland, and to verify whether monetary or fiscal dominant regimes prevailed in these countries. In the backward-looking approach, the long-term relationship between present primary surplus and the lagged public debt is analyzed. In the most 
empirical studies the co-integrating relationship between the primary surplus and the lagged level of debt is estimated: ${ }^{1}$

$$
s_{t}=\alpha+\beta b_{t-1}+\varepsilon_{t}
$$

where: $\mathrm{s}_{\mathrm{t}}$ is the primary surplus to GDP ratio at time $t, b_{t-1}$ is the public debt to GDP ratio at time $\mathrm{t}-1$, and $\varepsilon_{\mathrm{t}}$ is an error term. The positive and statistically significant values of $\beta(\beta>0)$ would indicate the prevalence of monetary dominant regime, while $\beta \leq 0$ would indicate fiscal dominant regime.

However, before getting into the co-integration analysis, the properties of the time series have to be checked. Following the methodology applied by Afonso and Jalles (2012), in the first step of our analysis we test for the existence of a unit root in the first-differenced debt time series. This is the simples test for the fiscal policy sustainability, since an unit root in the first-difference level of debt would indicate that the debt is explosive. Next, we investigate the stationarity of the debt and primary surplus time series. Non-stationary and integrated in the same order time series would allow test for co-integration. For the completeness and robustness purposes, several tests for unit root are performed: Augmented Dickey-Fuller, PhillipsPerron and Ng-Perron test. However, in the presence of structural breaks in the series, the above mentioned tests may be biased toward non-rejection of the unit root. Therefore, additionally, two tests allowing for structural break in the series are performed: the Zivot-Andrews (1992, pp. 251-270) test and the Perron (1997, pp. 355-385) test. The Zivot-Andrews test allows for one structural break and the break point is endogenously determined from the data. $^{2}$ The null of the test is of a unit root and the alternative hypothesis is of stationarity with structural break. The Perron test also allows for one structural break at an unknown time, but it allows for the structural break to occur under both the null and the alternative hypothesis.

If the test results indicate that the two variables are I(1) process, we can test for the existence of co-integrating relationship between primary balance and lagged debt. We use Johansen procedure for this purpose. However, this test does not account for possible structural break, changing the cointegration relationship, which might occur during analyzed period. In this case the test would under-reject the null of no co-integration. Therefore, the Gregory and Hansen (1996, pp. 99-126) procedure is applied to test for the

\footnotetext{
${ }^{1}$ It is also possible to estimate the co-integrating relationship between government revenues and expenditures in order to test for the fiscal sustainability.

${ }^{2}$ The break date is selected where the t-statistic from the ADF test is at a minimum.
} 
structural shift in the co-integrating relationship. The null of the test is of no co-integration and the alternative of co-integration with a break.

If the existence of co-integrating relationship is confirmed, the next step of the analysis is estimation of the parameter $\beta$ in the co-integration equation. The estimation is made using Dynamic Ordinary Least Squares (DOLS). As discussed above, negative or not statistically significant $\beta$ would suggest fiscal dominance regime while $\beta>0$ - monetary dominance regime. However, the positive estimate of $\beta$ may also be consistent with the fiscal dominance regime, since a positive value of $\beta$ may be observed, when an increase in previous period debt leads to an increase in primary surplus (MD regime) but also when a decrease in expected primary surplus leads to decrease in the current debt ratio through a price increase, which is consistent with FD regime (Bajo-Rubio et al., 2009, pp. 525-539). Therefore, for positive estimates of $\beta$, the analysis is complemented by Grangercausality test. Causality running from primary surplus to debt suggest FD regime, while causality from debt to primary surplus suggest MD regime.

For the cases where both primary balance and the public debt prove to be $\mathrm{I}(0)$ processes, we estimate the equation using least squares with breaks. The conclusions regarding the estimates of parameter $\beta$ are the same as described above.

The procedure for analyzing the fiscal sustainability described above consist of several steps. At each stage of the analysis, we can conclude that the conditions for fiscal solvency are not fulfilled. For example, if we conclude that the primary balance and the public debt are integrated of different orders, it would mean that there is no long-run relationship between these two variables (including a positive one), and the fiscal policy is not sustainable. To summarize the description of the methodology used in this study, Figure 1 presents the possible results on each stage of the analysis. 
Figure 1. The sequence of the empirical methodology

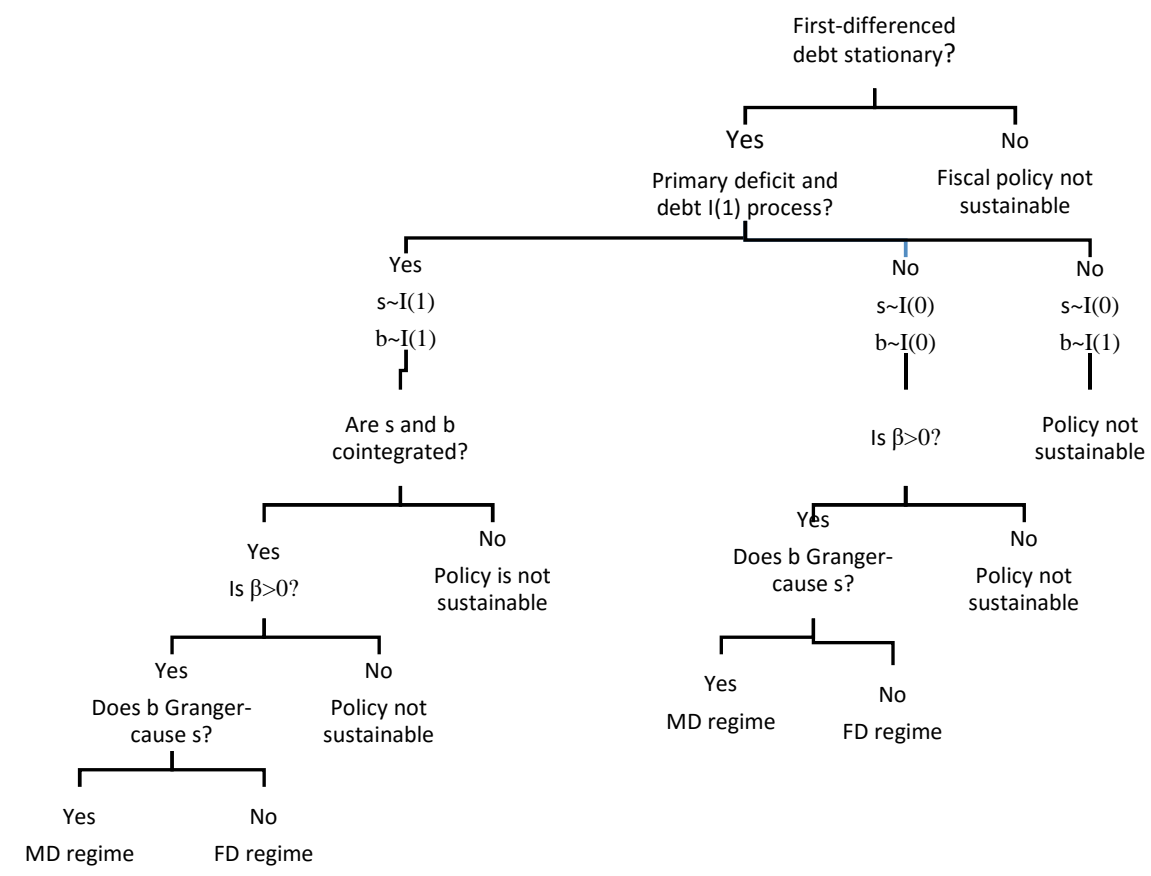

Source: own preparation.

The issue of fiscal sustainability in the context of fiscal theory of the price level has been addressed in several empirical studies. Taking approach described above Bajo-Rubio et al. (2009, pp. 924-937) tested the FTPL for 11 EMU countries over the period 1970-2005. They found that in the countries, with the exception of Finland, fiscal policy was sustainable and monetary dominant regime prevailed. More recently, the same authors (Bajo-Rubio et al., 2014, pp. 924-937) analyzed the relationship between primary surplus and debt for Spain over the period 1850-2000. Their results suggest that although the condition of fiscal solvency was fulfilled, the whole period can be characterized as one of fiscal dominance. Afonso and Jalles (2012) assessed the fiscal sustainability in OECD countries over the period 1970-2010, time-series analysis as well as panel technics. Their results were, however, less optimistic. They found an absence of public finances sustainability in the case of most countries, while the Ricardian 
regime was identified in 12 countries. Legrenzi and Milas (2012) analyzed fiscal sustainability in Greece, Ireland, Portugal and Spain, allowing for non-linearity in behavior of fiscal variables. Their results suggest the existence of a threshold effect: the countries seem to correct their policies only if the unbalances are large.

There are very limited number of empirical tests for FTPL for transition economies. Notable example is a study of Komulainen and Pirttilä (2002, pp. 293-316). They used unstructural VAR models of prices, exchange rate, money and fiscal balance for Bulgaria, Romania and Russia. They stated that their results do not support the existence of fiscal dominance in these countries but the method allows for no clear contradiction of FTPL. Fiscal sustainability in CEE countries was tested on the basis of time-series analysis, for example in Llorca and Redzepagic (2008, pp. 159-172), Stoian and Câmpeanu (2010), and Stanek (2014). Llorca and Redzepagic (2008) examine panel of eight new EU Member States (including the Czech Republic, but excluding Hungary). They use data on public expenditure and revenues and on the basis of panel unit root tests and panel co-integration tests find that fiscal policy in these countries is sustainable in the long run. Stoian and Câmpeanu (2010, pp. 501-518) estimate fiscal reaction functions for all CEE countries. A positive reaction of primary surplus to debt is found in the case of five countries (including the Czech Republic and Hungary), while a negative one is found in the case of four countries (including Poland). Stanek (2014, pp. 22-37) investigates the impact of Euro adoption by the new Member States on the sustainability of their fiscal stance. Using panel stationarity tests, he finds that there are no significant differences concerning debt sustainability between new EMU members and the other CEE countries, outside EMU.

\section{Empirical analysis}

Fiscal policy in the Czech Republic, Hungary and Poland

Among countries under consideration most serious fiscal problems were experienced by Hungary. The public debt ratio was rising from 2001, mostly as a result of deterioration of the primary balance. The public debt to GDP was rising continuously until 2006, when the government realized that the high primary deficit cannot be sustained any longer. Several important measures were implemented in order to improve the public finances. As a result of these actions, the primary balance became positive in 2008. How- 
ever, severe economic slowdown caused by the global financial crisis engendered again an increase in the debt ratio, magnified by the effect of significant depreciation of forint, which increased the value of debt denominated in foreign currencies. Apart from these developments, two important events influenced the public finances in Hungary. Firstly, in 2008, the Hungarian government took out a loan from IMF/EU credit facility, which added 5.5 per cent of GDP to the debt. Secondly, in 2011 a reform of the pension system took place, which resulted in a transfer of 90 per cent of portfolio managed by private pension funds to the Pension Reform and Debt Reduction Fund. An important part of the portfolio consisted of government securities which were withdrawn by the debt management agency. This operation resulted in a reduction of the debt by 4.9 per cent of GDP. (Magyar Nemzeti Bank, 2012). At the end of the analyzed period the public debt in Hungary amounted to about $80 \%$ of GDP, which was well above the $60 \%$ level set in the Maastricht Treaty.

In comparison with Hungary, the public debt level in the Czech Republic may seem low. However, in early 2000s, due to a loose fiscal policy and very high budget deficits, the public debt was rising. In 2004, a large Public Finance Reform took place. The fiscal consolidation, which was evenly distributed between expenditure and revenue measures, resulted in a decline in fiscal deficit and stabilization of debt. However, in the following years fiscal policy started to loosen again and the outburst of the global financial crisis caused the government to implement some fiscal stimulus measures, worsening the situation further (IMF, 2013). In 2010, fiscal consolidation started again and consisted primarily of revenue measures like an increase in value added tax and excise taxes and some cuts in benefit entitlements (ECB, 2010). At the end of the sample the public debt amounted however to $46 \%$ of GDP and was 30 per cent of GDP higher than in 2000. 
Figure 2. Primary balance as per cent of GDP

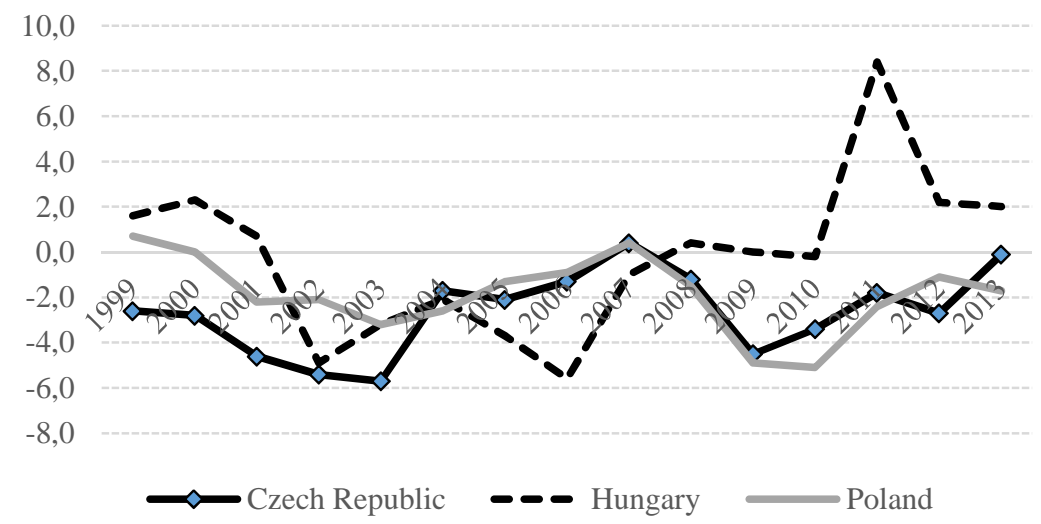

Source: own preparation based on Eurostat data.

Figure 3. General government debt as per cent of GDP

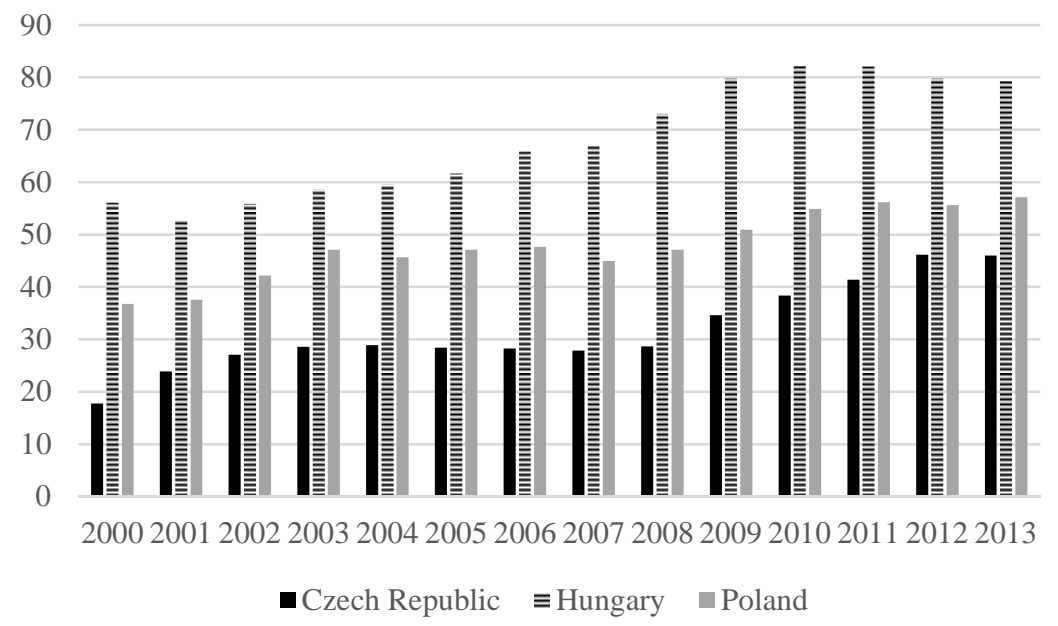

Source: own preparation based on Eurostat data.

Poland was also among countries which were running large fiscal deficits in 2000s. This policy led to a significant increase in debt to GDP ratio. Several steps, including tax reform, were taken in order to improve the government balance. The fiscal consolidation has been quite successful, since the budget deficit was decreasing for several years and in 2007 the 
public debt decreased for the first time since 2004. However, economic slowdown resulting from financial crisis and lower income tax revenues caused the public finance situation to worsen again and the budget deficit amounted to 7,9 percent of GDP in 2009. Further consolidation measures were implemented, including tightened eligibility for early retirement, a ceiling of CPI+1 on the growth of discretionary expenditures and VAT and excise taxes increase. As a result, the deficit decreased, however remained still quite high and the debt to GDP increased further. Recent changes in the pension system (transfer of funds from the pension second pillar to the general government) will improve public finance statistics, but they will cause only a one-time reduction in the level of debt and the effect of this reform goes beyond the time frames of the study.

\section{Data and results}

To overcome to some extent the difficulties coming from very short samples for the analyzed countries, we use quarterly data on government finance coming from the Eurostat database. ${ }^{3}$ The primary balance is the general government budget balance excluding the general government interest payments and is expressed in percent of GDP. The debt stock is the general government consolidated gross debt in percent of GDP. The data have been seasonally adjusted. The sample period begins in Q1 2000 and ends in Q3 2013.

In the first step of our analysis, we test for the stationarity of the first difference of the government debt. As described above, for the robustness purposes we conduct Augmented Dickey-Fuller test, Phillips-Perron test and the Ng-Perron test. As the sample period includes the financial crisis, which created challenge for fiscal policy, we conduct also unit root tests allowing for structural breaks in the series - Zivot-Andrews test and Perron (1997) test. The tests results are summarized in Table 1. The results suggest that in all three countries the null of a unit root should be rejected, so it leads to the conclusion that this condition for fiscal solvency is satisfied. The break-type test report breaks in the series in the second half of 2008 or the beginning of 2009.

${ }^{3}$ Although to the analysis of fiscal policy yearly data would be obviously preferred, short time-series for transition economies would unable such analysis. However, it is not unusual to use quarterly fiscal data in empirical studies (see for example Stoian \& Campeanu, 2010, pp. 501-518; Baldi \& Staehr, 2013; Haug et al., 2013; Franta, 2012; Stanek, 2014, pp. 22-37). 
Table 1. Unit root tests for the first-difference of the public debt

\begin{tabular}{|c|c|c|c|c|c|c|}
\hline & ADF & PP & \multicolumn{4}{|c|}{ NP } \\
\hline & & & $\mathrm{MZa}$ & $\mathrm{MZt}$ & MSB & MPT \\
\hline $\mathrm{CZ}$ & $-3.13 * *$ & $-7.10 * * *$ & $-11.64 * *$ & $-2.35 * *$ & $0.20 * *$ & $2.36 * *$ \\
\hline HU & $-8.00 * * *$ & $-8.12 * * *$ & $-26.40 * * *$ & $-3.63 * * *$ & $0.14 * * *$ & $0.93 * * *$ \\
\hline PL & $-6.50 * * *$ & $-6.50 * * *$ & $-26.25 * * *$ & $-3.61 * * *$ & $0.14 * * *$ & $0.97 * * *$ \\
\hline & \multicolumn{3}{|c|}{$\mathbf{Z A}$} & \multicolumn{3}{|c|}{$\mathbf{P}$} \\
\hline $\mathrm{CZ}$ & \multicolumn{3}{|c|}{$\begin{array}{c}-2.93 \\
2008 Q 4\end{array}$} & \multicolumn{3}{|c|}{$\begin{array}{c}-9.00 * * * \\
2008 Q 3\end{array}$} \\
\hline HU & \multicolumn{3}{|c|}{$\begin{array}{c}-7.01 * * * \\
2008 Q 4\end{array}$} & \multicolumn{3}{|c|}{$\begin{array}{c}-10.87 * * * \\
2009 Q 1\end{array}$} \\
\hline PL & \multicolumn{3}{|c|}{$\begin{array}{c}-6.33 * * * \\
2008 Q 4\end{array}$} & \multicolumn{3}{|c|}{$\begin{array}{c}-7.32 * * * \\
2008 Q 3\end{array}$} \\
\hline
\end{tabular}

Source: own calculations.

In order to verify the relationship between primary surplus and the debt stock, one first has to check the order of integration of the analyzed series. The same order of integration would allow for testing for co-integration between the primary surplus and lagged level of public debt. The results of the unit root tests for these two variables are presented in Table 2.

The results of the standard unit root tests suggests the rejection of the null in the case of the Czech Republic and Hungary. In the case of Poland, only the ADF test leads to the rejection of the unit root hypothesis, while Phillips-Perron and the $\mathrm{Ng}$ and Perron tests suggest that primary balance in Poland is a unit root process. The test allowing for the structural break in the series confirm the unit root in the case of Poland and add the Czech Republic to the countries where primary balance is non-stationary. 
Table 2. Unit root tests for the primary balance and the debt stock

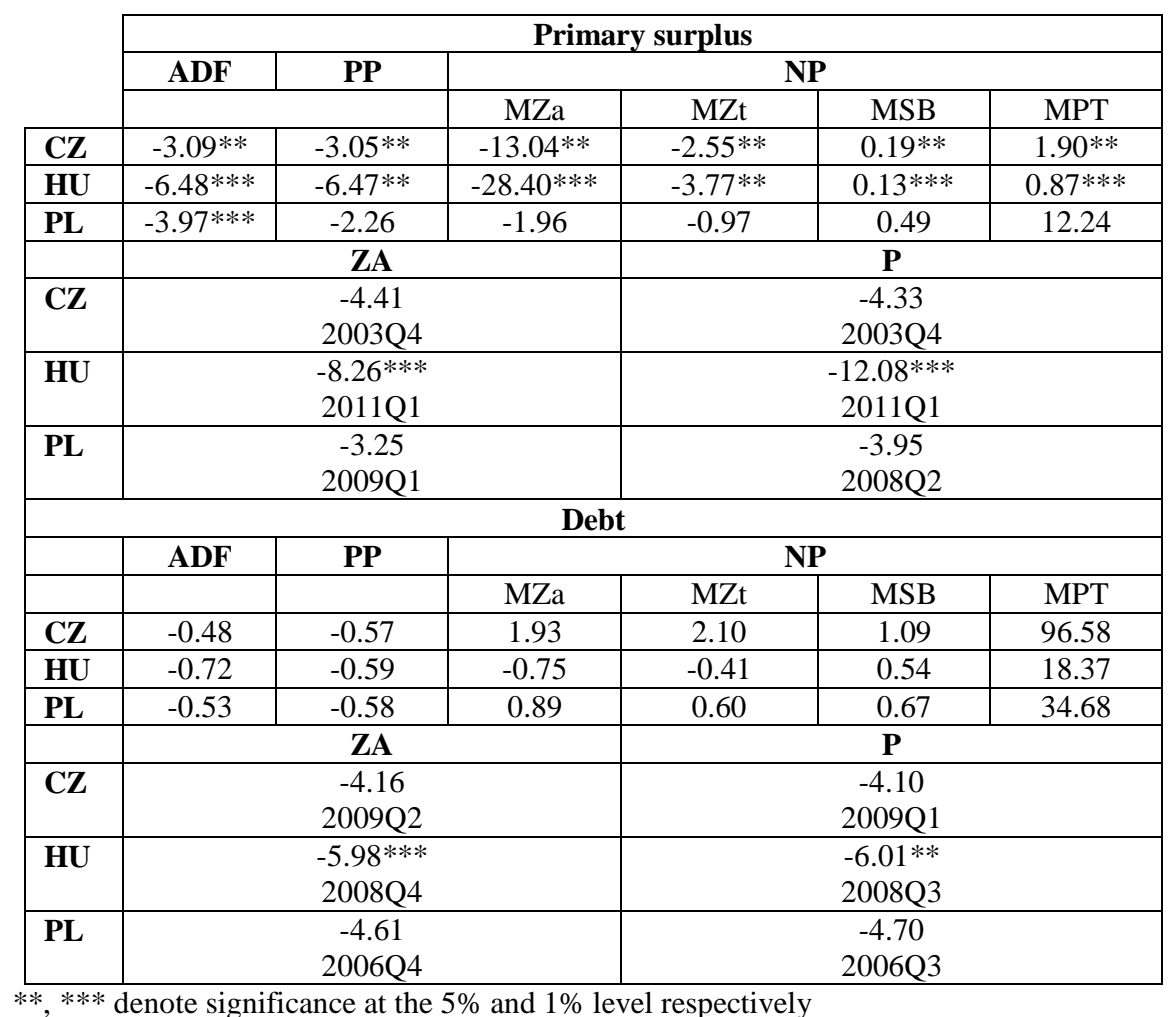

Source: own calculations.

For those countries, where the public debt and the primary balance proved to be I(1) process (i.e. the Czech Republic and Poland), we analyze the co-integrating relationship between those two variables, as suggested by Bohn (2007, pp. 1837-47). As we use quarterly data, we check the relationship between primary surplus and the debt lagged by 4 periods. Table 3 . presents results for the Johansen co-integration test. 
Table 3. Johansen co-integration test for primary balance and lagged debt

\begin{tabular}{|l|l|c|c|c|c|}
\cline { 2 - 6 } \multicolumn{1}{c|}{} & $\begin{array}{c}\text { Hypothesized } \\
\text { no. of CE }\end{array}$ & $\begin{array}{c}\text { Trace } \\
\text { statistic }\end{array}$ & $\begin{array}{c}\text { Critical } \\
\text { value } \\
\mathbf{( 0 . 0 5 )}\end{array}$ & $\begin{array}{c}\text { Max-eigen } \\
\text { statistic }\end{array}$ & $\begin{array}{c}\text { Critical } \\
\text { value } \\
\mathbf{( 0 . 0 5}\end{array}$ \\
\hline \multirow{2}{*}{$\begin{array}{l}\text { Czech } \\
\text { Republic }\end{array}$} & None & 36.03 & 20.26 & 31.43 & 15.89 \\
\cline { 2 - 6 } & At most 1 & 4.61 & 9.16 & 4.61 & 9.16 \\
\hline \multirow{2}{*}{ Poland } & None & 17.74 & 20.26 & 14.61 & 15.89 \\
\cline { 2 - 6 } & At most 1 & 3.13 & 9.16 & 3.13 & 9.16 \\
\hline
\end{tabular}

Source: own calculations.

The results of the test indicate one co-integrating relationship between primary surplus and lagged debt in the case of the Czech Republic (at the $5 \%$ level), but no co-integration in the case of Poland. This would suggest that the public finances in Poland were not sustainable. However, as the previous test suggested structural breaks in the series, there may also be structural break in the co-integrating relationship. We test for the possibility using Gregory and Hansen test. We use the model with level shift and trend. The results of the test are presented in Table 4.

Table 4. Gregory-Hansen test for structural shift in co-integrating relationship

\begin{tabular}{|l|c|c|c|c|}
\cline { 2 - 5 } \multicolumn{1}{c|}{} & \multicolumn{2}{c|}{ ADF test } & \multicolumn{2}{c|}{ Phillips test } \\
\cline { 2 - 5 } \multicolumn{1}{c|}{} & ADF* stat & Break date & $\mathbf{Z}_{\alpha}^{*}$ stat & Break date \\
\hline $\begin{array}{l}\text { Czech Repub- } \\
\text { lic }\end{array}$ & $-5.21 * *$ & $2008 \mathrm{Q} 3$ & -35.11 & $2008 \mathrm{Q} 3$ \\
\hline Poland & -4.04 & $2009 \mathrm{Q} 4$ & -12.44 & $2008 \mathrm{Q} 3$ \\
\hline
\end{tabular}

** denotes significance at the 5\% level. Critical values from the Gregory and Hansen (1996, pp. 99-126).

Source: own calculations.

The Gregory and Hansen test confirms the results of Johansen cointegration test, since we reject the null of no co-integration for the Czech Republic, while we cannot reject the null in the case of Poland. Therefore, we conclude that in the case of Poland there is no evidence of the existence of the relationship between the primary surplus and lagged levels of the public debt. No such relationship suggests the prevalence of fiscal dominance regime in Poland in the analyzed period. 
The last step of the analysis is the estimation of the parameter $\beta$ in the co-integrating relationship in the equation [5]. The parameter is estimated using the DOLS. Positive and statistically significant $\beta$ would indicate prevalence of the monetary dominance regime and sustainability of the fiscal policy, while negative $\beta$ or not statistically different from zero would indicate the regime of fiscal dominance. The analysis is performed for the Czech Republic, as for the country the co-integrating relationship between primary surplus and lagged debt was found, as well as for Poland to confirm the previous results of no co-integration. The estimated equation contains (beside lagged values of the debt) dummy for the year 2008, as for the most series in 2008 break in the data was indicated. In the case of the Czech Republic, the equation also contains a dummy for the fourth quarter of 2001. The estimation results are presented in Table 5. In both countries, the estimated parameters prove to be negative and statistically significant indicating no sustainability of public finances.

Table. 5. Estimation of parameter $\beta$ in co-integrating relationship between primary balance and debt

\begin{tabular}{|c|c|c|}
\hline & Czech Republic & Poland \\
\hline$\beta$ & $-1.41 * *(0.59)$ & $-1.09 *(0.55)$ \\
\hline $\mathrm{C}$ & $-1.85^{* * * *}(0.54)$ & $-1.59 * * *(0.46)$ \\
\hline Dummy 2008 & $0.46(1.40)$ & $-0.62(1.50)$ \\
\hline Dummy 2001Q4 & $-6.98 * * *(2.53)$ & -- \\
\hline $\mathrm{R}^{2}$ & 0.52 & 0.28 \\
\hline
\end{tabular}

Source: own calculations.

For Hungary, where the tests reported structural breaks in the series but no unit root process, the relationship between primary surplus and lagged debt stock is estimated using least squares with breaks. Estimated parameter is positive and statistically significant (Table 6.). 
Table 6. Estimation results of relationship between primary balance and debt for Hungary

\begin{tabular}{|l|c|}
\cline { 2 - 2 } \multicolumn{1}{c|}{} & Estimation result \\
\hline $\boldsymbol{\beta}$ & $\mathbf{0 . 2 6}^{* * *}(\mathbf{0 . 0 9})$ \\
\hline $\mathrm{C}$ & $-18.06^{* * *}(6.07)$ \\
\hline $\mathrm{R}^{2}$ & 0.15 \\
\hline
\end{tabular}

$*, * *, * * *$ denote significance at the $10 \%, 5 \%$ and $1 \%$ level respectively. Standard error in parentheses.

Source: Own calculations.

However, as already described, positive values of $\beta$ may occur under MD as well as under FD regime. In order to verify if the regime in Hungary was monetary dominant or fiscal dominant, Granger causality test is performed. Somewhat surprisingly, the results (presented in Table 7) indicate that the causality runs from the public debt to primary surplus, suggesting the prevalence of monetary dominant regime in Hungary.

Table 7. Granger causality test

\begin{tabular}{|l|c|c|}
\hline \multicolumn{1}{|c|}{ Causality direction } & F-statistic & Prob. \\
\hline $\mathrm{B}_{\mathrm{t}-1} \rightarrow \mathrm{s}_{\mathrm{t}}$ & 4.18 & 0.007 \\
\hline $\mathrm{s}_{\mathrm{t}-1} \rightarrow \mathrm{B}_{\mathrm{t}}$ & 0.25 & 0.90 \\
\hline
\end{tabular}

Source: own calculations.

\section{Conclusions}

In this study we have tested the sustainability of fiscal policy and the existence of monetary versus fiscal dominance in three central and eastern European economies: the Czech Republic, Hungary and Poland. The empirical methodology was based on the analysis of the long-run relationship between primary balance and lagged public debt (the so called backwardlooking approach). Existence of positive, statistically significant relationship indicates the MD regime.

The results obtained suggest that over the analyzed period in the Czech Republic and Poland FD regime prevailed, while in Hungary it was MD regime. These results may seem surprising, taking into account that Hungary is a heavily indebted country, while the Czech Republic belongs to group of countries with relatively low debt to GDP ratio. However, although in 
the Czech Republic the public debt is relatively small, it was rising significantly over the analyzed period despite fiscal consolidation and therefore results indicate, that this policy is not sustainable in the long term. Similar situation occurred in Poland - fiscal consolidation measures aimed at reducing debt proved to be not enough to prevent debt from rising in the face of adverse developments after beginning of the global financial crisis. On the other hand, in Hungary a one-time reduction in debt caused by changes in pension system improved the fiscal situation and primary surpluses generated, since then helped to stabilize the debt. Further fiscal consolidation measures applied in the Czech Republic and Poland may also change the conclusions about fiscal sustainability over next years, so this could be a field for future research.

\section{References}

Afonso, A., \& Jalles, J. T. (2012). Revisiting fiscal sustainability. Panel cointegration and structural breaks in OECD countries. ECB Working Paper 1465. http://dx.doi.org/10.2139/ssrn.2180575.

Bajo-Rubio, O., Díaz-Roldán, C., \& Esteve, V. (2009). Deficit sustainability and inflation in EMU: An analysis from the Fiscal Theory of the Price Level. European Journal of Political Economy, 25(4).

Bajo-Rubio, O., Díaz-Roldán, C., \& Esteve, V. (2014). Deficit sustainability, and monetary versus fiscal dominance: The case of Spain, 1850-2000. Journal of Policy Modelling, 36(5), http://dx.doi.org/10.1016/j.jpolmod.2014.07.004.

Baldi, G., \& Staehr, K. (2013). The European debt crisis and fiscal reaction functions in Europe 2000-2012. DIW Berlin Discussion Papers, 1295.

Bohn, H. (1998). The behavior of U.S. debt and deficits. Quarterly Journal of Economics, 113.

Bohn, H. (2007). Are stationarity and cointegration restrictions really necessary for the intertemporal budget constraint?. Journal of Monetary Economics, 54, http://dx.doi.org/10.1016/j.jmoneco.2006.12.012.

Canzoneri, M. B., Cumby, R. E., \& Diba, B. T. (2001). Is the price level determined by the needs of fiscal solvency?. American Economic Review, 91, http://dx.doi.org/10.1257/aer.91.5.1221.

Christiano, L., \& Fitzgerald, T. (2000). Understanding the fiscal theory of the price level. NBER Working Paper 7668.

Cochrane, J. (2000). Money as stock: price level determination with no money demand. NBER Working Paper 7498.

Cochrane, J. (2001). Long-term debt and optimal policy in the fiscal theory of the price level. Econometrica, 69(1), http://dx.doi.org/10.1111/1468-0262.00179.

European Central Bank (2010). The impact of the financial crisis on the central and eastern European countries. ECB Monthly Bulletin, July 2010. 
Franta, M. (2012). Macroeconomic effects of fiscal policy in the Czech Republic: Evidence based on various identification approaches in a VAR framework. Czech National Bank Working Paper 13/2012.

Gregory, A., \& Hansen B. (1996). Residual-based tests for cointegration in models with regime shifts. Journal of Econometrics, 70, http://dx.doi.org/10.1016/030 4-4076(69)41685-7.

Haug, A., Jędrzejowicz, T., \& Sznajderska, A. (2013). Combining monetary and fiscal policy in an SVAR for a small open economy. National Bank of Poland Working Paper 168.

International Monetary Fund (2013). Czech Republic, IMF Country Report No. $13 / 243$.

Komulainen, T., \& Pirttilä, J.(2002). Fiscal explanations for inflation: Any evidence from transition economies?. Economics of Planning, 35.

Leeper, E. (1991). Equilibria under active and passive monetary policies. Journal of Monetary Economics, 27, http://dx.doi.org/10.1016/0304-3932(91)90007-B.

Legrenzi, G., \& Milas, C. (2012). Debt sustainability and financial crises: Evidence from the GIIPS, CESifo Working Paper 3594.

Llorca, M., Redzepagic, \& S. (2008). Debt sustainability in the EU New Member States: empirical evidence from a panel of eight Central and East European countries. Post-Communist Economies, 20(2), http://dx.doi.org/10.1080/14 631370802018882.

Magyar Nemzeti Bank (2012). Public Finance Review, May 2012.

Perron, P. (1997). Further evidence on breaking trend functions in macroeconomic variables. Journal of Econometrics, 80(2), http://dx.doi.org/10.1016/S03044076(97)00049-3.

Sims, C. (1994). A simple model for the determination of the price level and the interaction of monetary and fiscal policy. Economic Theory, 4, http://dx.doi. org/10.1007/BF01215378.

Sims, C. (1999). Fiscal consequences for Mexico of adopting the dollar. mimeo.

Stanek, P. (2014). Public debt sustainability and the participation of the new member states in the euro area. Poznań University of Economics Review, 14(4).

Stoian, A., \& Câmpeanu, E. (2010). Fiscal policy reaction in the short term for assessing fiscal sustainability in the long run in Central and Eastern European countries. Czech Journal of Economics and Finance, 60(6).

Woodford, M. (1994). Monetary policy and price level determinacy in a cash-inadvance economy. Economic Theory, 4, http://dx.doi.org/10.1007/BF01215 377.

Woodford, M. (1995). Price level determinacy without control of a monetary aggregate. Carnegie-Rochester Series on Public Policy, 43(1), http://dx.doi.org/ 10.1016/0167-2231(95)00038-0.

Woodford, M. (1996). Control of the public debt: a requirement for price stability?. NBER Working Paper 5684.

Woodford, M. (1998). Comment on Cochrane. NBER Macroeconomics Annual, MIT Press. 
Woodford, M. (2001). Fiscal requirement for price stability. Journal of Money, Credit, and Banking, 33(3), http://dx.doi.org/10.2307/2673890.

Zivot, E., \& Andrews D. (1992). Further evidence on the great crash, the oil-price shock and the unit root hypothesis. Journal of Business and Economic Statistics, 10(3), http://dx.doi.org/10.2307/1391541. 